\title{
Studi Analisis Pengaruh Model Sudu Turbin Terhadap Putaran Pada Pembangkit Listrik Tenaga Mikro Hidro (PLTMH)
}

\author{
Donny Christiawan ${ }^{1}$, Lie Jasa ${ }^{2}$, Yanu Prapto Sudarmojo ${ }^{3}$
}

\begin{abstract}
Micro-hydro power plants are usually built in areas that have the potential of discharge water and head low. In this study, writers do an investigation of the micro-hydro turbine blade to obtain more effective results with greater RPM, output voltage, shape or placement of the nozzle position. The model of the blade used is a semi-circular blade, triangular blade, the blade fins. RPM speed measurements from the three types of turbines, calculated from $0^{0}, 5^{0}, 10^{0}, 15^{0}, 20^{\circ}, 25^{0}, 30^{\circ}, 35^{\circ}$ and $40^{\circ}$, to compare the magnitude of rpm generated on every degree of the nozzle. After getting the rpm speed of the three types of turbine then showed the amount of torque to each type of turbine. Data extents best to accommodate water flow equation is used LAM 1, 2 LAM, LAM 3, and the volume of LAM 3. From the measurements that have been carried out, the results obtained from the measurements of a top speed is 151.6 RPM and highest torque is $0,017 \mathrm{Nm}$ at angle nozzle turbine blade 300 that is in the triangle. As for the area's best water discharge volume is a halfcircle blade amounted to 3.19 liters. From the research, the best turbine is triangular blade because it gets optimal rpm and torque at an angle of $30^{\circ}$, while the blade semi-circular is the best blade to accommodate the flow of water.
\end{abstract}

Intisari- Pembangkit listrik mikro hidro biasanya dibangun pada daerah yang memiliki potensi debit dan head yang rendah Dalam penelitian ini dilakukan investigasi terhadap sudu turbin mikro hidro untuk mendapatkan hasil yang lebih efektif dengan rpm yang lebih besar, keluaran tegangan, dan posisi nozzle. Model sudu yang digunakan yaitu sudu setengah lingkaran, sudu segitiga, sudu sirip. Pengukuran kecepatan rpm dari ketiga model turbin, dihitung dari sudut nozzle $0^{0}, 5^{0}, 10^{0}, 15^{0}, 20^{0}, 25^{0}$, $30^{\circ}, 35^{\circ}$ dan $40^{\circ}$, untuk membandingkan besaran rpm yang dihasilkan pada setiap sudut nozzle. Hasil yang didapatkan dari ketiga model turbin maka didapatkan hasil perhitungan torsi untuk masing - masing jenis turbin. Data luasan untuk menampung luasan air digunakan persamaan LAM 1, LAM 2, LAM 3, dan volume LAM 3. Hasil pengukuran yang dilakukan, diperoleh rpm tertinggi sebesar 151,6 dan torsi tertinggi sebesar $0,017 \mathrm{Nm}$ pada sudut nozzle $30^{\circ}$ yaitu pada sudu turbin segitiga. Sedangkan untuk luasan air terbaik adalah sudu setengah lingkaran sebesar 3,19 liter. Dari hasil penelitan didapat turbin yang paling baik adalah turbin model sudu segitiga karena menghasilkan rpm dan torsi optimal pada sudut $30^{\circ}$.

${ }^{1}$ Mahasiswa Teknik Elektro dan Komputer Fakultas Teknik Universitas Udayana, Kampus Bukit Jimbaran, Badung Bali. 80361, Tel. 0361703315 fax. 703315;email: donny_christiawan@ymail.com

${ }^{2,3}$ Dosen Teknik Elektro dan Komputer Fakultas Teknik Universitas Udayana, Kampus Bukit Jimbaran, Badung Bali. 80361, Tel.0361703315 fax.703315;email: liejasa@unud.ac.id
Kata Kunci- turbin, mikro hidro, sudu, LAM.

\section{PENDAHULUAN}

Energi tenaga air adalah energi yang berasal dari air yang mengalir yang digunakan untuk memutar turbin, yang selanjutnya dihubungkan dengan generator. Untuk memutar kincir /turbin air, diperlukan air dalam jumlah yang konstan sehingga putaran kincir yang memutar generator juga konstan. Semakin besar jumlah air yang memutar kincir maka semakin kuat energi kinetis yang dihasilkan, tentunya semakin besar energi yang kita dapatkan. Potensi aliran air yang dapat digunakan untuk pembangkit mikro hidro diantaranya: saluran irigasi, persawahan, air terjun dengan ketinggian tertentu, aliran air dengan kecepatan tertentu, atau bendungan yang dibangun untuk pengendali banjir. Di lokasi tersebut tentunya akan sulit mendapatkan ijin untuk membangun sebuah pembangkit mikro hidro. Dilain pihak energi listrik merupakan kebutuhan vital masyarakat yang harus mendapat perhatian lebih dari pemerintah, sehingga tidak menimbulkan krisis listrik yang berkepanjangan [1],[2],[3],[4].

Pulau Bali adalah salah satu pulau yang berada di wilayah Indonesia dan beriklim tropis yang memiliki dua musim yaitu musim kemarau dan musim penghujan. Musim penghujan menjadikan air akan melimpah bahkan dapat menyebabkan banjir. Air yang melimpah dapat dimanfaatkan untuk memutar turbin untuk menghasilkan energi listrik. Energi listrik yang dihasilkan dari pembangkit listrik tenaga air merupakan salah satu sumber energi terbarukan yang murah, bersih dan ramah lingkungan. Sungai-sungai yang ada di wilayah Indonesia potensial digunakan sebagai pembangkit mikro hidro. Pembangkit listrik mikro hidrobiasanya dibangun pada daerah yang memiliki potensi pembangkit energi listrik dalam kapasitas kecil. Bedasarkan ketinggian jatuhnya air (head) maka turbin dapat diklarifikasikan bedasarkan head tinggi, head sedang, head rendah [3].

Parameter desain yang berpengaruh terhadap turbin pembangkit listrik mikro hidro (PLTMH) adalah jumlah sudu, bentuk sudu, diameter turbin, rpm, lebar turbin, sudut nozzle, dan posisi nozzle [5].

Pada Penelitian ini jumlah sudu turbin yang digunakan pada model sudu setengah lingkaran berjumlah 16 sudu, sedangkan model sudu segitiga; dan sudu sirip berjumlah 8 sudu. Dalam penelitian awal penulis ingin melihat apakah jumlah sudu berpengaruh pada rpm, namun karena air yang jatuh kedalam sudu turbin menggunakan pompa yang debitnya tetap. Sehingga banyaknya sudu pada turbin tidak terlihat pengaruhnya antara jumlah sudu 8 dan 16. Tetapi dalam perhitungan LAM dan uji coba secara manual, 
perlakuan jumlah sudu 8 dan 16 sama untuk ketiga model. Penelitian tidak menghitung daya keluaran, hanya menghitung luasan LAM untuk mendapatkan besaran torsi, sehingga daya dianggap tetap.

\section{Pembangkit Listrik tenaga Mikro Hidro}

\section{A. Pengertian Pembangkit Listrik Tenaga Mikro Hidro}

PLTMH merupakan pembangkit listrik dengan memanfaatkan aliran sungai (skala kecil) untuk menghasilkan daya listrik dengan menggunkanan turbin air dengan generator. Turbin air berperan untuk mengubah energi air (energi potensial, tekanan dan energi kinetik) menjadi energi mekanik dalam bentuk putaran poros.[7]

PLTMH memanfaatkan aliran air untuk menghasilkan energi listrik. Kapasitas dari PLTMH tidak melebihi dari 100 KW. Indonesia memiliki potensi air yang sangat besar dan belum dimanfatkan secara optimal. [8].

Pembangkit listrik tenaga air, merupakan sumber energi yang paling murah, karena merupakan transformasi energi dari energi kinetis berupa pergerakan aliran air menjadi energi listrik dengan memanfaatkan generator yang diputar dengan turbin air. Untuk memutar turbin air,diperlukan air dalam jumlah yang konstan sehingga putaran kincir yang memutar generator juga konstan. Semakin besar jumlah air yang memutar kincir maka semakin kuat energi kinetis yang dihasilkan, tentunya semakin besar energi yang kita dapatkan [2].

Sistem pembangkit listrik tenaga air skala kecil di bagi menjadi 3 golongan, yaitu: piko hidro dengan kapasitas dari beberapa watt sampai dengan $1 \mathrm{KW}$, mikro hidro dengan kapasitas antara 1 - $100 \mathrm{KW}$, dan mini hidro dengan kapasitas $100 \mathrm{KW}$ samapai dengan $1 \mathrm{MW}$ [9].

Beberapa komponen yang digunakan untuk pembangkit Listrik Tenaga Mikro Hidro baik komponen utama maupun bangunan penunjang antara lain: [10].

\section{Bangunan Pemasok Air}

Pada umumnya bangunan pemasok air pada PLTMH adalah bangunan terjun (air terjun) dan saluran irigasi yang memiliki potensi air tinggi.

\section{Bak Pengendap}

Bak penenang berfungsi menampung aliran air dari saluran irigasi sebagai cadangan kekurangan debit air yang akan digunakan, untuk kemudian dialirkan melalui pipa pesat.

\section{Pipa Pesat (Penstock)}

Penstock dihubungkan pada sebuah elevasi yang lebih rendah ke sebuah roda air, dikenal sebagai sebuah turbin.

4.Turbin

Turbin berfungsi untuk mengkonversi energi aliran air menjadi energi putaran mekanis.

5. Nozzle

Nozzle terletak diujung pipa pesat yang berfungsi untuk memampatkan aliran air sehingga air yang keluar mempunyai tekanan yang tinggi dan mampu memutar turbin.

6. Generator

Generator berfungsi untuk menghasilkan listrik dari putaran mekanis.

Donny Christiawan: Studi Analisis Pengaruh Model...

\section{Governoor}

Untuk mengatur masuknya air dari pipa pesat (penstock) menuju turbin digunakan governor. Model governor dapat diklasifikasikan dalam beberapa bentuk, seperti hidrolik mekanik, elektro hidrolik dan mekanik governor [11].

B. Desain Sudu Turbin

1. Sudu Turbin Segitiga

Model turbin dibuat dalam posisi berdiri, dan sudu yang ditempatkan di tepi lingkaran luar antara dua piringan roda. Dalam penelitian ini jumlah sudu dirancang, 8 buah berbentuk segitiga yang melekat di tepi roda seperti gambar 1. [3].

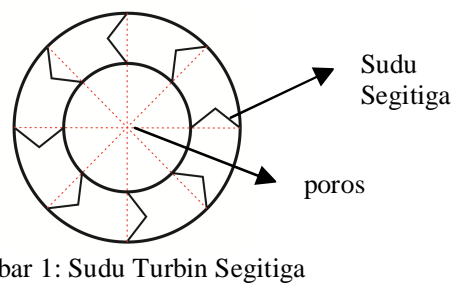

2. Sudu Turbin sirip

Turbin sudu sirip adalah turbin air yang memiliki sudu-sudu berbentuk sirip yang dipasang pada bagian tepi dari pinggirian roda dalam penelitian ini jumlah sudu berjumlah 8 buah sudu,seperti gambar 2 [3].

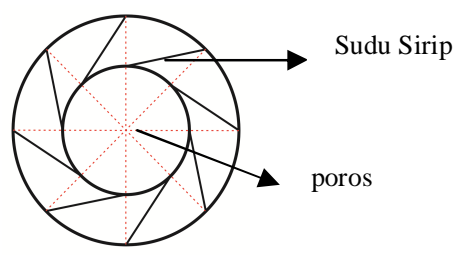

Gambar 2: Sudu Turbin Sirip

3. Sudu Turbin Setengah Lingkaran

Turbin setengah lingkaran dibuat dari duah buah piringan sejajar yang digabungkan oleh sederatan sudu melengkung di bagian tepi dalam penelitian ini jumlah sudu di rancang 16 buah sudu, seperti gambar $3[3]$.

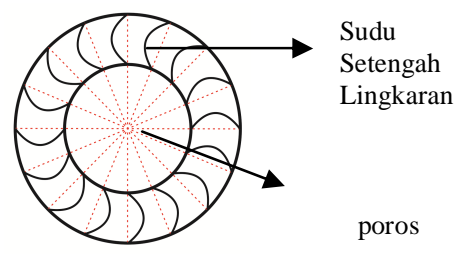

Gambar 3: Turbin Setengah Lingkaran

\section{Arah Sudut Nozzle}

Panjang dari lengan nozzle harus lebih besar dari jari-jari roda sehingga nozzle selalu berada diluar dari lingkaran roda. Sudut $\alpha$ adalah sudut yang terbentuk antara lengan nozzle dengan nozzle. Besarnya $\alpha$ di buat antara $0^{\circ}, 5^{\circ}, 10^{\circ}, 15^{\circ}, 20^{\circ}$, $25^{\circ}$, dan $30^{\circ}$, bertujuan untuk membandingkan besaran rpm

p-ISSN:1693 - 2951; e-ISSN: 2503-2372 
yang dihasilkan pada setiap sudut nozzle. Pada sudut $35^{\circ}$ dan $40^{\circ}$ air sudah tidak mengenai sudu turbin. Range sudut $\alpha<90^{\circ}$, dengan arah ditunjukan pada sudu, seperti terlihat pada gambar 4 [5].

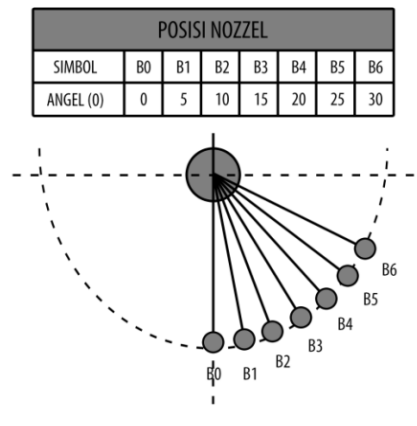

Gambar 4: Arah Sudut Nozzle

\section{Torsi Turbin}

Daya output dan kecepatan putaran turbin berbeda pada setiap pergantian sudut nozzlenya, maka torsi turbin dapat dihitung sebagai berikut:

Generator yang dipakai adalah dinamo sepeda, karena dinamo sepeda merupakan generator yang berukuran kecil serta dapat menghasilkan energi listrik, walaupun digerakkan dengan putaran (rpm) yang tidak terlalu tinggi. Daya nominal generator adalah 6 watt dan kecepatan putaran nominal generator yang didapat dari pengukuran adalah $1800 \mathrm{rpm}$, maka torsi pada generator dapat dihitung sebagai berikut [10] :

$$
T=\frac{P}{2 \pi \frac{n}{60}}
$$

Dimana :

$\mathrm{T}=$ Torsi $(\mathrm{Nm})$

$\mathrm{P}=$ Daya $(\mathrm{W})$

$\mathrm{n}=$ Putaran (rpm)

\section{E. Luasan Sudu Turbin}

Desain luasan air yang terapung pada sudu turbin adalah luasan yang terbentuk karena adanya perpaduan luas antara lingkaran luar $\left(\mathrm{L}_{1}\right)$ dan lingkaran dalam $\left(\mathrm{L}_{2}\right)$. jari - jari dari ke tiga lingkaran yang terbentuk adalah $r_{1}, r_{2}$ dan $1 / 2\left(r_{1}+r_{2}\right)$ ketiga lingkaran ada pada titik pusat yang sama. Inisial LAM diambil dari inisial Lie Jasa, Ardyono Priyadi, Mauridhi Hery Purnomo dan besarnya LAM 1 adalah [2]:

$\mathrm{L}_{\operatorname{lam} 1}=\frac{\pi}{N}\left(2 \mathrm{r}_{1} \mathrm{r}_{2}+\mathrm{r}_{1}^{2}-3 \mathrm{r}_{2}^{2}\right)$

Dimana:

$$
\begin{aligned}
& \mathrm{r}_{1}=\text { Jari }- \text { jari lingkaran luar } \\
& \mathrm{r}_{2}=\text { Jari }- \text { jari lingkaran dalam } \\
& \mathrm{N}=\text { Jumlah sudu }
\end{aligned}
$$

\section{Luasan LAM 2}

Luasan LAM 2 adalah luasan yang terbentuk dari luas lingkaran luar $\left(\mathrm{L}_{1}\right)$ dikurangi dengan luas lingkaran dalam $\left(\mathrm{L}_{2}\right)$ dibagi dengan banyaknya sudu $\mathrm{N}$ [2].

$\mathrm{L}_{\operatorname{lam} 2}=\frac{\pi}{N}\left(\mathrm{r}_{1}^{2}-\mathrm{r}_{2}^{2}\right)$.

Dimana:

$$
\begin{aligned}
& \mathrm{r}_{1}=\text { Jari }- \text { jari lingkaran luar } \\
& \mathrm{r}_{2}=\text { Jari }- \text { jari lingkaran dalam } \\
& \mathrm{N}=\text { Jumlah sudu }
\end{aligned}
$$

\section{Luasan LAM 3}

Luasan LAM 3 adalah luasan air yang tertahan pada masing - masing sudu, dengan sudut $11,25^{\circ}$, persentase luasan yang terbentuk pada tiap - tiap sudu terlihat pada masing masing tabel persentase sudu. Persentase luas tiap sudu dihitung bedasarkan perbandingan nilai luasan tiap sudu dengan luasan LAM 2. Sudut sudu adalah sudut yang terbentuk searah jarum jam dihitung mulai sumber vertical [2]. $\mathrm{L}_{\text {lam } 3}=\mathrm{X}\left\{\frac{\pi}{N}\left(\mathrm{r}_{1}{ }^{2}-\mathrm{r}_{2}{ }^{2}\right)\right\}$

Dimana:

$$
\begin{aligned}
& \mathrm{r}_{1}=\text { Jari }- \text { jari lingkaran luar } \\
& \mathrm{r}_{2}=\text { Jari }- \text { jari lingkaran dalam } \\
& \mathrm{N}=\text { Jumlah sudut sudu } \\
& \mathrm{X}=\text { Luasan total pada masing }- \text { masing sudu }
\end{aligned}
$$

\section{Volume LAM 3}

Untuk menentukan besarnya volume LAM3 adalah dihitung bedasarkan luasan LAM 3 dikalikan dengan lebar turbin. Misalkan lebar sebuah turbin adalah W, maka volume LAM 3 dapat dihitung dengan rumus [2]:

$\mathrm{V}_{\text {LAM } 3}=\mathrm{X} . \mathrm{W}\left\{\frac{\pi}{N}\left(\mathrm{R}_{1}{ }^{2}-\mathrm{R}_{2}{ }^{2}\right)\right\}$

Dimana:

$$
\begin{aligned}
& \mathrm{r}_{1}=\text { Jari }- \text { jari lingkaran luar } \\
& \mathrm{r}_{2}=\text { Jari }- \text { jari lingkaran dalam } \\
& \mathrm{N}=\text { Jumlah sudut sudu } \\
& \mathrm{X}=\text { Luasan total pada masing }- \text { masing sudu } \\
& \mathrm{W}=\text { Lebar pada turbin }
\end{aligned}
$$

\section{Metode PenElitian}

Langkah-langkah penelitian yang dilakukan ada 6 tahapan diantaranya Studi pustaka, analisis disain, analisis matematis, pengambilan data analisis perbandingan hasil pengukuran dapat dilihat pada gambar 5:

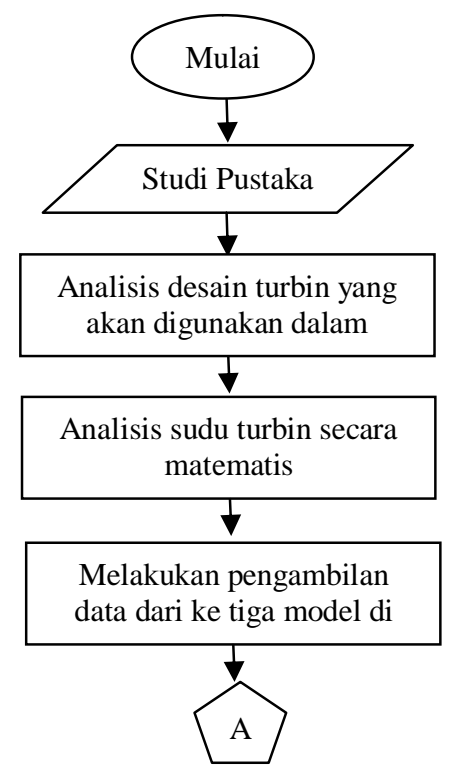




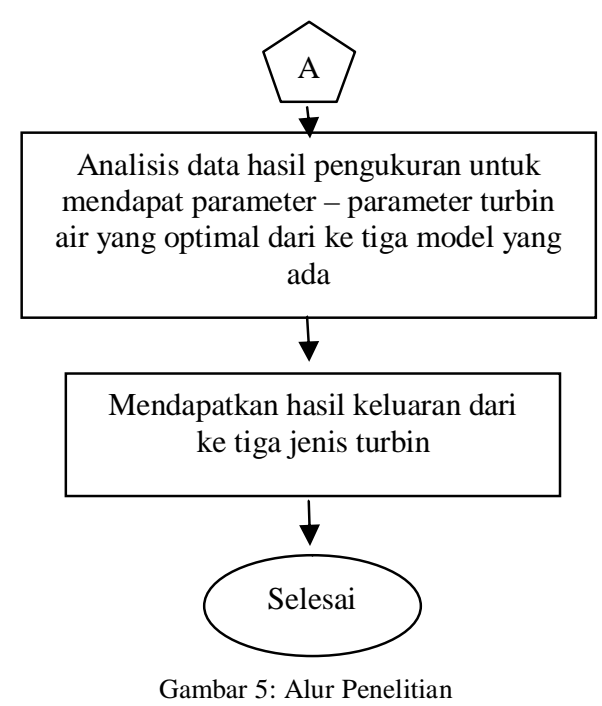

a. Studi Pustaka

Mencari refrensi - refrensi atau buku tentang pembangkit listrik mikro hidro. Selanjutnya mencari jurnal - jurnal dan artikel tentang pemasangan atau kinerja turbin.

b. Analisis Desain Sudu Turbin

Mendesain atau merancang model sudu turbin yang akan digunakan dalam penelitian ini.Model sudu yang digunakan dalam penelitian ini yaitu: sudu setengah lingkaran, sudu segitiga, dan sudu sirip.

\section{c. Analisis Sudu Turbin Secara Matematis}

Menentukan sudut dari $5^{0}, 10^{\circ}, 15^{0}, 20^{\circ}, 25^{\circ}, 30^{\circ}, 35^{\circ}$, dan $40^{\circ}$ untuk mengukur kecepatan rpm dari masing - masing turbin yang digunakan. Setelah dapat mengukur kecepatan rpm pada masing - masing jenis turbin dari sudut yang sudah ditentukan, maka dari hasil pengukuran kecepatan rpm tersebut dapat dihitung torsi dari ke tiga jenis turbin tersebut.Menghitung luasan sudu yaitu: LAM1, LAM2, LAM3, dan volume LAM3 dari masing - masing model sudu turbin.

d. Melakukan Pengambilan Data Dari Ketiga Model Turbin

Pada penelitian ini diasumsikan generator bersifat loosless (efisiensi 100\%). Untuk pengambilan data yang pertama yaitu mengukur kecepatan rpm dari ketiga jenis turbin, yang sudutnya dihitung dari $5^{0}, 10^{\circ}, 15^{0}, 20^{\circ}, 25^{\circ}, 30^{\circ}, 35^{\circ}$, dan $40^{\circ}$, sehingga dapat menentukan posisi sudut yang baik untuk menentukan jatuhnya air ke dalam turbin supaya mendapatkan putaran yang optimal.Setelah mendapatkan hasil kecepatan rpm dari ketiga jenis turbin yang telah diukur, maka didapatkan hasil perhitungan torsi untuk masing - masing jenis turbin.
Selanjutnya menghitung secara matematis untuk luasan LAM1, LAM2, LAM3, dan volume LAM3 untuk mendapatkan data luasan yang paling baik untuk menampung luasan debit air.

\section{e. Analisis Data Untuk mernemukan Parameter Turbin Yang} Optimal

Dari hasil pengukuran yang telah dilakukan maka didapatkan posisi sudut yang tepat dengan jatuhnya air ke dalam turbin, sehingga mendapatkan kecepatan rpm yang maksimal. Setelah mendapatkan rpm yang maksimal dari ke tiga jenis turbin maka mendapatkan hasil perhitungan torsi dari masing - masing turbin untuk mengetahui putaran setiap turbin.Dari hasil pengukuran volume sudu dan perhitungan matematis LAM1, LAM2, LAM3, dan volume LAM3 yaitu untuk mengetahui luasan sudu yang paling baik menampung debit air dalam jumlah banyak.

\section{f. Mendapatkan Hasil Keluaran Dari Ketiga Jenis Turbin}

Setelah mendapatkan semua data hasil pengukuran yang dilakukan secara maksimal, maka dapat diketahui hasil yang optimal dari masing - masing turbin yaitu mendapatkan karakteristik perubahan besar sudut terhadap kecepatan rpm dari ketiga jenis turbin yang diukur.Mengetahui hasil perhitungan besaran torsi pada masing - masing turbin yang digunakan dalam penelitian ini.Mengetahui luasan volume sudu yang cocok digunakan untuk menampung debit air dalam jumlah besar.

\section{HASIL DAN PEMBAHASAN}

Hasil yang dibahas pada penelitian ini yaitu, pengukuran putaran turbin, putaran rpm generator, tegangan masingmasing turbin, arus dari masing-masing turbin, daya dari masing-masing turbin, perhitungan torsi pada masing-masing turbin, perhitungan LAM 1, LAM 2, LAM 3, dan volume LAM 3 pada masing-masing turbin.

\section{A. Pengukuran RPM turbin}

Grafik dari Putaran rpm turbin dari masing - masing jenis turbin di lihat pada gambar 6:

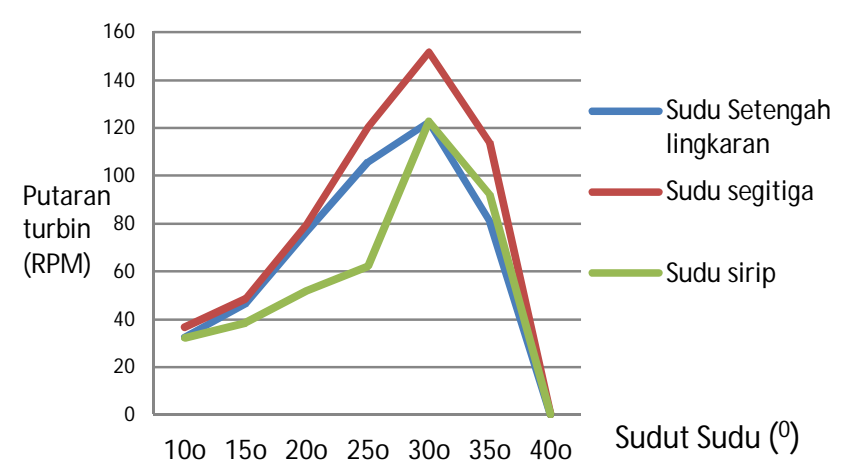

Gambar 6: RPM Turbin dari Ketiga Model Sudu Turbin 
Pada gambar 6 menunjukkan putaran turbin pada masingmasing sudu mencapai titik optimal pada sudut $30^{\circ}$. Pada sudut optimal tersebut, putaranrata - rata turbin sudu setengah lingkaran sebesar 122,4, turbin sudu segitiga sebesar 151,6 dan rata - rata turbin sudu sirip sebesar 122,8. Sehingga dari ketiga jenis sudu turbin tersebut, putaran turbin yang paling optimal adalah turbin sudu segitiga yang nilai rata - rata puterannya sebesar 151,6. Perubahan nilai tinggi pada putaran setiap turbin berbeda-beda, dikarenakan jenis sudu masingmasing turbin memiliki kharakteristik sudu yang berbeda.

\section{B. Pengukuran RPM Generator}

Grafik dari Putaran rpm generator dari masing - masing jenis turbin di lihat pada gambar 7 :

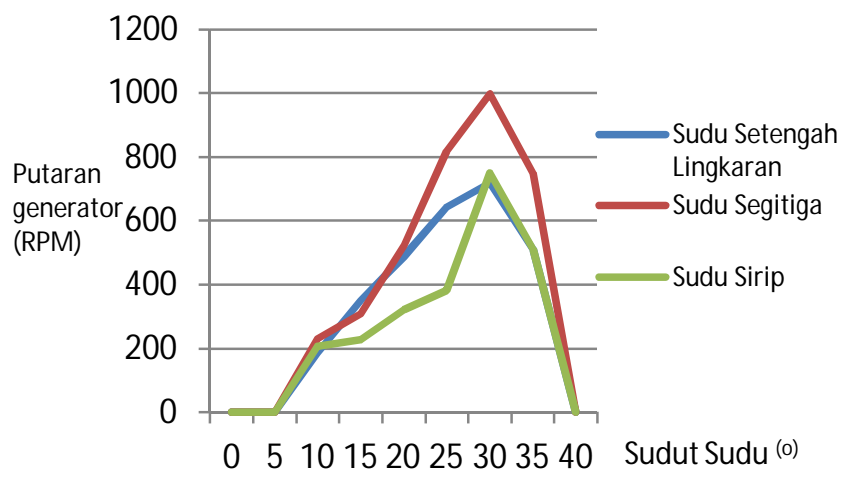

Gambar 7: RPM Generator Dari Ketiga Model Sudu Turbin

Pada gambar 7 menunjukkan, putaran generator pada masing-masing sudu mencapai titik optimal pada sudut $30^{\circ}$. Pada sudut optimal tersebut, putaran rata - rata generator sudu setengah lingkaran sebesar $718 \mathrm{rpm}$, turbin sudu segitiga sebesar $997 \mathrm{rpm}$ dan rata - rata turbin sudu sirip sebesar 751 rpm.

\section{Tegangan (V) Dari Ketiga Mod el Turbin}

Grafik tegangan dari masing - masing jenis turbin di lihat pada gambar 8:

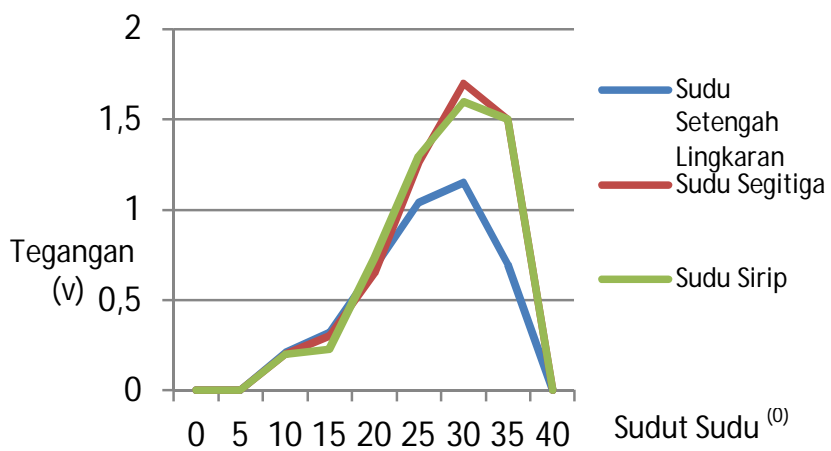

Gambar 8: Tegangan (V) Dari Ketiga Model Sudu Turbin

Pada gambar 8 menunjukkan, grafik tegangan pada masingmasing sudu mencapai titik optimal pada sudut $30^{\circ}$. Pada sudut optimal tersebut,output tegangan pada sudu setengah lingkaran sebesar $1,15 \mathrm{~V}$, turbin sudu segitiga sebesar $1,7 \mathrm{~V}$ dan turbin sudu sirip sebesar 1,6 V.

\section{Arus (I) Dari Ketiga Model Sudu Turbin}

Grafik Arus dari masing - masing jenis turbin di lihat pada gambar 9:

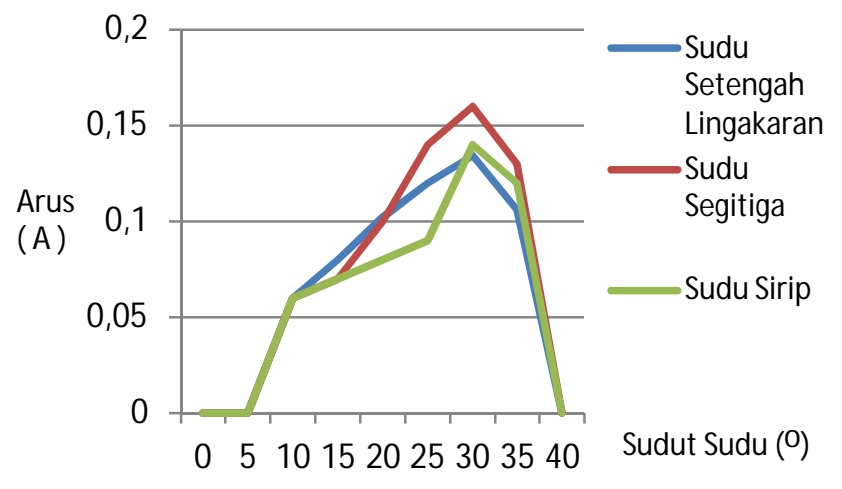

Gambar 9: Besarnya Arus (I) Dari Ketiga Model Sudu Turbin

Pada gambar 9 menunjukkan, arus pada masing-masing sudu mencapai titik optimal pada sudut $30^{\circ}$. Pada sudut optimal tersebut, arus sudu setengah lingkaran sebesar 0,134 $\mathrm{mA}$, turbin sudu segitiga sebesar $0,16 \mathrm{~mA}$ dan sudu sirip sebesar $0,14 \mathrm{~mA}$.

\section{E. Pengukuran Daya (P) Dari Ketiga Model Sudu Turbin}

Grafik daya dari masing - masing jenis turbin di lihat pada gambar 8:

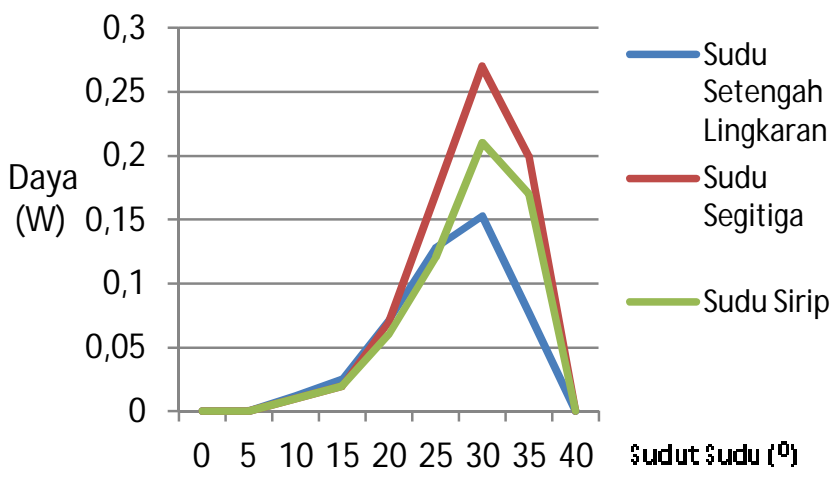

Gambar 10: Daya (P) Dari Ketiga Model Sudu Turbin

Pada gambar 10 menunjukkan, daya keluaran pada masingmasing sudu mencapai titik optimal pada posisi nozzle sudut $30^{\circ}$. Pada sudut optimal tersebut, output daya sudu setengah lingkaran sebesar $0,153 \mathrm{~W}$, turbin sudu segitiga sebesar 0,27 W dan sudu sirip sebesar $0,21 \mathrm{~W}$.

\section{F. Perhitungan Torsi Pada Sudu Turbin Setengah Lingkaran}

Daya output dan kecepatan putaran turbin berbeda setiap pergantian sudut nozzlenya, maka torsi turbin dapat dihitung sebagai berikut:

Daya nominal generator adalah 6 watt dan kecepatan putaran nominal generator yang diperoleh dari pengukuran 
adalah $1800 \mathrm{rpm}$, maka torsi pada generator dapat dihitung dengan menggunakan persamaan (1) sebagai berikut:

$$
\begin{aligned}
& T=\frac{6}{2 * 3,14 * \frac{1800}{60}} \\
& =\frac{6}{2 * 3,14 * 30} \\
& =0,032 \mathrm{Nm}
\end{aligned}
$$

Daya output dan kecepatan putaran turbin berbeda setiap pergantian sudut nozzelnya, untuk perhitungan torsi sudu turbin setengah lingkaran pada setiap sudut nozzle.

Perhitungan torsiturbin pada sudut nozzle $30^{\circ}$ dapat dihitung dengan menggunakan persamaan (1) sebagai berikut:

$$
\begin{aligned}
T & =\frac{0,153}{2 * 3,14 * \frac{122}{60}} \\
& =0,012
\end{aligned}
$$

\section{G. Perhitungan Torsi Pada Sudu Turbin Segitiga}

Daya output dan kecepatan putaran turbin berbeda setiap pergantian sudut nozzelnya, untuk perhitungan torsi sudu turbin segitiga pada setiap sudut nozzle dapat dilihat pada tabel II. Perhitungan torsiturbin pada sudut nozzle $30^{\circ}$ dapat dihitung dengan menggunakan persamaan (1) sebagai berikut:

$$
\begin{aligned}
T & =\frac{0,27}{2 * 3,14 * \frac{152}{60}} \\
& =0,017
\end{aligned}
$$

H. Perhitungan Torsi Pada Sudu Turbin Sirip

Daya output dan kecepatan putaran turbin berbeda setiap pergantian sudut nozzelnya, untuk perhitungan torsi sudu turbin sirip pada setiap sudut nozzle dapat dilihat pada tabel III. Perhitungan torsi turbin pada sudut nozzle $30^{\circ}$ dapat dihitung dengan menggunakan persamaan (1) sebagai berikut:

$$
\begin{aligned}
T & =\frac{0,21}{2 * 3,14 * \frac{122}{60}} \\
& =0,016
\end{aligned}
$$

Hasil perhitungan torsi pada ke tiga sudu dapat dilihat pada gambar 11:

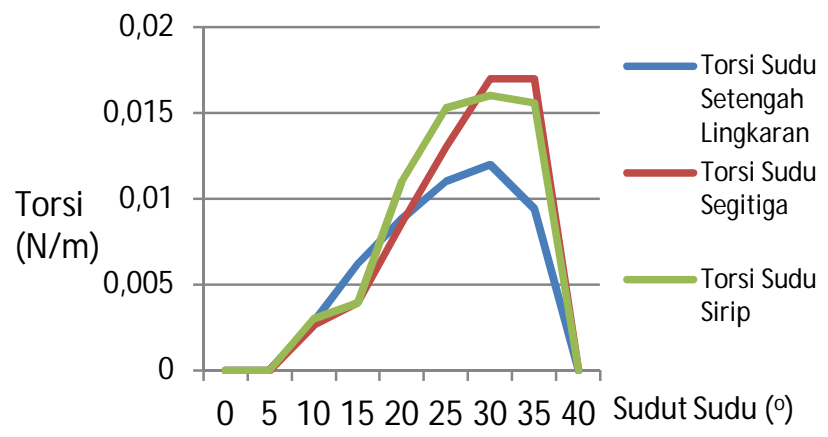

Gambar 11: Perhitungan Torsi Pada Ke tiga jenis sudu
Pada gambar 11 menunjukkan hasil perhitungan torsi pada pemodelan pembangkit listrik tenagamikro hidro. Dari perhitungan yang telah dilakukan dapat di lihat nilai torsi di sudut $30^{\circ}$ sebesar $0.017 \mathrm{Nm}$ pada sudu segitiga.

\section{Perhitungan LAM 1, LAM 2, LAM 3, Dan Volume LAM 3}

Pada Sudu Setengah Lingkaran

Sudu Setengah lingkaran diketahui jari - jari luar $\left(\mathrm{r}_{1}\right)$ sebesar $25 \mathrm{~cm}$, dan jari - jari dalam $\left(\mathrm{r}_{2}\right)$ sebesar $14,5 \mathrm{~cm}, \pi$ sebesar 3,14, jumlah sudut sudu (N) sebesar 16, luasan total pada masing - masing sudu (X) sebesar 3,92, dan lebar turbin (W) sebesar $10 \mathrm{~cm}$.

1) Luasan LAM 1

Untuk menghitung luasan LAM 1 menggunakan persamaan (2):

$$
\begin{aligned}
& =\frac{3,14}{16}\left(2 \cdot 25 \cdot 14,5+25^{2}-3 \cdot 14,5^{2}\right) \\
& =141,18 \mathrm{~cm}^{2}
\end{aligned}
$$

2) Luasan LAM 2

Untuk menghitung luasan LAM 2 menggunakan persamaan (3):

$$
\begin{aligned}
& =\frac{3,14}{16}\left(25^{2}-14,5^{2}\right) \\
& =81,39 \mathrm{~cm}^{2}
\end{aligned}
$$

\section{3)Luasan LAM 3}

Untuk menghitung luasan LAM 3 menggunakan persamaan (4):

$$
\begin{aligned}
& =3,92\left\{\frac{3,14}{16}\left(25^{2}-14,5^{2}\right)\right\} \\
& =3190 \mathrm{~cm}^{2}
\end{aligned}
$$

4) Volume LAM 3

Untuk menghitung volume LAM 3 menggunakan persamaan (5):

$$
\begin{aligned}
& =3,92.10 \mathrm{~cm}\left\{\frac{3,14}{16}\left(25^{2}-14,5^{2}\right)\right\} \\
& =3.19 \text { liter }
\end{aligned}
$$

\section{J. Perhitungan LAM 1, LAM 2, LAM 3, Dan Volume LAM3}

Pada Sudu Segitiga

Sudu Segitiga diketahui jari - jari luar $\left(\mathrm{r}_{1}\right)$ sebesar $25 \mathrm{~cm}$, dan jari - jari dalam $\left(r_{2}\right)$ sebesar $14,5 \mathrm{~cm}, \pi$ sebesar 3,14 , jumlah sudut sudu $(\mathrm{N})$ sebesar 16, luasan total pada masing masing sudu (X) sebesar 2,85, dan lebar turbin (W) sebesar 10 $\mathrm{cm}$.

1) LuasanLAM 1

Untuk menghitung luasan LAM 1 menggunakan persamaan (2):

$$
\begin{aligned}
& =\frac{3,14}{16}\left(2 \cdot 25 \cdot 14,5+25^{2}-3 \cdot 14,5^{2}\right) \\
& =141,15 \mathrm{~cm}^{2}
\end{aligned}
$$


2) LuasanLAM 2

Untuk menghitung luasan LAM 2 menggunakan persamaan (3):

$=\frac{3,14}{16}\left(25^{2}-14,5^{2}\right)$

$=81,39 \mathrm{~cm}^{2}$

3) LuasanLAM 3

Untuk menghitung luasan LAM 3 menggunakan persamaan (4):

$=2,85\left\{\frac{3,14}{16}\left(25^{2}-14,5^{2}\right)\right\}$

$=231,96 \mathrm{~cm}^{2}$

4) Volume LAM 3

Untuk menghitung volume LAM 3 menggunakan persamaan (5):

$=2,85.10 \mathrm{~cm}\left\{\frac{3,14}{16}\left(25^{2}-14,5^{2}\right)\right\}$

$=2,31$ liter

K. Perhitungan LAM 1, LAM 2, LAM 3, dan Volume LAM3 Pada Sudu TurbinSirip

Sudu Sirip diketahui jari - jari luar $\left(\mathrm{r}_{1}\right)$ sebesar $25 \mathrm{~cm}$, dan jari - jari dalam $\left(\mathrm{r}_{2}\right)$ sebesar $14,5 \mathrm{~cm}, \pi$ sebesar 3,14 , jumlah sudut sudu $(\mathrm{N})$ sebesar 16, luasan total pada masing - masing sudu $(\mathrm{X})$ sebesar 3,60, dan lebar turbin $(\mathrm{W})$ sebesar $10 \mathrm{~cm}$.

1) LuasanLAM 1

Untuk menghitung luasan LAM 1 menggunakan persamaan (2):

$=\frac{3,14}{16}\left(2 \cdot 25 \cdot 14,5+25^{2}-3 \cdot 14,5^{2}\right)$

$=141,15 \mathrm{~cm}^{2}$

2) LuasanLAM 2

Untuk menghitung luasan LAM 2 menggunakan persamaan (3):

$=\frac{3,14}{16}\left(25^{2}-14,5^{2}\right)$

$=81,39 \mathrm{~cm}^{2}$

3) LuasanLAM 3

Untuk menghitung luasan LAM 3 menggunakan persamaan (4):

$=3,60\left\{\frac{3,14}{16}\left(25^{2}-14,5^{2}\right)\right\}$

$=293 \mathrm{~cm}^{2}$

4) Volume LAM 3

Untuk menghitung volume LAM 3 menggunakan persamaan (5):

$=3,60.10 \mathrm{~cm}\left\{\frac{3,14}{16}\left(25^{2}-14,5^{2}\right)\right\}$

$=2,93$ liter

Hasil perhitungan LAM 1, LAM 2, LAM 3 dan volume LAM 3 pada masing - masing sudu turbin dapat dilihat pada tabel XI.
TABEL IX

HASIL PERHITUNGAN LAM 1, LAM 2, LAM 3, DAN VOLUME LAM 3

\begin{tabular}{|c|c|c|c|}
\hline Perhitungan & $\begin{array}{c}\text { Sudu Setengah } \\
\text { Lingkaran }\end{array}$ & Sudu Sirip & Sudu Segitiga \\
\hline Lam 1 & $141,18 \mathrm{~cm}^{2}$ & $141,15 \mathrm{~cm}^{2}$ & $141,15 \mathrm{~cm}^{2}$ \\
\hline Lam 2 & $81,39 \mathrm{~cm}^{2}$ & $81,39 \mathrm{~cm}^{2}$ & $81,39 \mathrm{~cm}^{2}$ \\
\hline Lam 3 & $319 \mathrm{~cm}^{2}$ & $293 \mathrm{~cm}^{2}$ & $231,96 \mathrm{~cm}^{2}$ \\
\hline Volume Lam 3 & 3,19 liter & 2,93 liter & 2,31 liter \\
\hline
\end{tabular}

Tabel XI menunjukan hasil perhitungan luasan LAM 1, LAM 2, LAM 3dan volume LAM 3 yang dilakukan secara maetematis pada masing - masing turbin.Sudu turbin setengah lingkaran adalah sudu yang paling banyak menampung debit air, sedangkan untuk sudu turbin segitiga dan sudu turbin sirip perhitungan secara matematis memiliki nilai yang lebih kecil dari sudu setengah lingkaran. Karena air yang dapat ditampung lebih sedikit dari turbin sudu setengah lingkaran

\section{KESIMPULAN}

Kesimpulan dari penelitian ini adalah sebagai berikut :

1. Pada posisi sudut nozzle $0^{0}, 5^{0}, 10^{\circ}, 15^{\circ}, 20^{\circ}, 25^{\circ}, 30^{\circ}, 35^{\circ}$, $40^{\circ}$ maka didapatkan rpm tertinggi pada turbin model sudu setengah lingkaran, turbin segitiga, turbin sirip didapat pada sudut $30^{\circ}$ masing-masing sebesar 122,4, $151,6,122,8$. Dari pengukuran tersebut sudu turbin segitiga adalah sudu turbin yang paling baik.

2. Dari ketiga jenis turbin didapatkan hasil perhitungan torsi pada masing - masing turbin dilakukan dengan perhitungan dengan menggunakan persamaan rumus. Sudu turbin segitiga mendapatkan torsi turbin yang paling tinggi adalah $0,017 \mathrm{Nm}$ pada sudut $30^{\circ}$.

3. Pengukuran volume air dari model masing - masing turbin diperoleh nilai tertinggi pada turbin setengah lingkaran yaitu sebesar 3,19 liter, sedangakan untuk turbin sirip dan segitiga diperoleh nilai masing - masing 2,93 liter dan 2,31 liter. Dari pengukuran tersebut, jika menggunakan debit air maka sudu setengah lingkaran yang paling cocok dipergunakan pada pemodelan pembangkit listrik tenaga mikro hidro.

4. Hasil dari penelitian ini turbin yang paling baik adalah turbin segitiga karena turbin model sudu segitiga menghasilkan rpm yang optimal dan torsi yang baik pada sudut $30^{\circ}$, sedangkan turbin model sudu setengah lingkaran yang paling banyak menampung volume air.

\section{REFERENSI}

[1] A. Indriani "Rancang Bangun dan Pembuatan Mode Sistem Pembangkit Listrik Tenaga Mikro Hidro Dengan Metode Elemen Hingga Bedasarkan Posisi Dan Bentuk Sudu Srew Pump”. Bengkulu : Universitas Bengkulu. 2013.

[2] Jasa, L., Ardana, P., Setiawan, I.N., 2011. Usaha Mengatasi Krisis Energi Dengan Memanfaatkan Aliran Pangkung Sebagai Sumber Pembangkit Listrik Alternatif Bagi Masyarakat Dusun Gambuk Pupuan-Tabanan, in: Proceding Seminar Nasional Teknologi Industri XV. Presented at the Seminar Nasional Teknologi Industri XV, ITS, Surabaya, pp. B0377-B0384

[3] L. Jasa."Investigasi sudut Nozzle dan sudut kelengkungan sudu turbin air untuk peningkatan efisiensi mikro hidro". Surabaya : ITS. 2015

[4] Jasa, L., Priyadi, A., Purnomo, M.H., 2014. An Alternative Model of Overshot Waterwheel Based on a Tracking Nozzle Angle Technique 
for Hydropower Converter | Jasa | International Journal of Renewable Energy Research (IJRER). Ilhami Colak 4, 1013-1019

[5] A. I. Weking, L. Jasa, Y. P. Sudarmojo "Modul Simulasi Kontrol Hidro Power Untuk Praktikum Mahasiswa Teknik Elektro". Badung : Universitas Udayana 2015.

[6] Negara, D.N.K.P.,"Kajian Potensi Pengembangan Pembangkit Listrik Tenaga Mikro Hidro Memanfaatkan Aliran Sungai Kelampuk Di Desa Tambalang-Buleleng". Teknik Mesin CakraM, vol.3 No.1, pp.121-126, Juni 2009.

[7] D P. D. Suparyawan., I N. S Kumara., W G. Ariastina. "Studi Perencanaan Pembangkit Listrik Mikro Hidro Di Desa Sambangan Kabupaten Buleleng Bali”. Majalah Ilmiah Teknologi Elektro. Vol. 12 No. 2.2013 .

[8] H.Y.S.H Nugroho and M. K. Sallata "Panduan Lengkap Membuat Sumber Energi Terbarukan Secara Swadaya". Yogyakarta. 2015.

[9] Parabelem T.D. R. "Analisis Pembangkit Listrik Tenaga Mikrohidro (PLTMH) Pada Daerah Aliran Sungai Ongkak Mongondow Di Desa Muntoi Kabupaten Bolaang Mongondow”. Jurnal Penelitian Saintek, Vol. 16, No 2. Oktober 2011.

[10] R A. Subakti., A. Susatyo. "Pengujian Prototipe Turbin Head Sangat Rendah Pada Suatu Saluran Aliran Air". Bandung: Pusat Penelitian Tenaga LIstrik Dan Mekatronik.2013.

[11] Jasa, L., Priyadi, A., Purnomo, M.H., 2012. PID Control for MicroHydro Power Plants based on Neural Network. ACTAPRESS doi:10.2316/P.2012.769-039. 